\title{
Control of Microdochium albescens in pre-germinated and dryland rice seeds
}

\author{
Bruno Tabarelli Scheidt ${ }^{*}$ (iD Evandro Zacca Ferreira ${ }^{1}$ (iD Flávio Chupel Martins ${ }^{1}$ (iD \\ Juliano Berghetti ${ }^{1}$ (D) Marília Michalski De Pieri $^{1}$ (D) Ricardo Trezzi Casa ${ }^{1}$ (D)
}

${ }^{1}$ Programa de Pós-graduação em Produção Vegetal (PPGPV), Universidade do Estado de Santa Catarina (UDESC), 88520-000, Lages, SC, Brasil. E-mail: brunotabarelli.s@hotmail.com. "Corresponding author.

ABSTRACT: The fungus Microdochium albescens can interfere in the germination of seeds and in the death of rice seedlings; however there is not technical indication for its control by seed treatment. This research evaluated the efficiency of fungicides in the treatment of pre-germinated and dryland rice seeds in the control of M. albescens. Seeds of the cultivars, Epagri 109, SCS116 Satoru, SCS121 CL and SCS122 Miura were treated with the following fungicides ( $\mathrm{g}$ a.i./100 kg of seeds): fluazinam + thiophanate methyl (9.45 + 63), pyraclostrobin + thiophanate methyl $(5+45)$, carboxin + thiram $(60+60)$, metalaxyl-M + thiabendazole + fludioxonil $(3+22.5+3.75)$, carbendazim + thiram (45 + 105), carbendazim (45). Seeds without fungicide treatment constituted the control. The treated seeds were sown in potato-sucroseagar (PSA) culture medium and incubated at $25 \pm 2{ }^{\circ} \mathrm{C}$ and photoperiod of 12 hours for 14 days. Treated seeds were also submitted to the germination test. Fluazinam + thiophanate methyl and metalaxyl-M + thiabendazole + fludioxonil showed greater control of $M$. albescens, not differing statistically between them, in the five cultivars and in the two cultivation systems. The tested fungicides provided seed germination above $90 \%$ in the four cultivars.

Key words: Fungicide, Oryza sativa, Seed treatment.

Controle de Microdochium albescens em sementes de arroz pré-germinado e sequeiro

RESUMO: O fungo Microdochium albescens pode interferir na germinação de sementes e na emergência de plântulas de arroz, porém não há indicação técnica para seu controle via tratamento de semente. Este trabalho teve como objetivo avaliar a eficiência de fungicidas em tratamento de sementes de arroz pré-germinado e sequeiro no controle de M. albescens. Sementes das cultivares Epagri 109, SCS116 Satoru, SCS121 CL e SCS122 Miura foram tratadas com os seguintes fungicidas (g i.a./100 kg de sementes): fluazinam + tiofanato metílico (9,45 $+63)$, piraclostrobina + tiofanato metílico $(5+45)$, carboxina + tiram $(60+60)$, metalaxil- $M+$ tiabendazol + fludioxonil $(3+22,5+$ 3,75), carbendazim + tiram (45 + 105), carbendazim (45). Sementes sem tratamento com fungicida constituíram a testemunha. As sementes tratadas foram semeadas em meio de cultura de batata-sacarose-ágar (BSA) e incubadas a $25 \pm 2{ }^{\circ} \mathrm{C}$ e fotoperiodo de 12 horas por 14 dias. Sementes tratadas também foram submetidas ao teste de germinação. Fluazinam + tiofanato metilico e metalaxil-M + tiabendazol + fludioxonil apresentaram maior controle de M. albescens, não diferindo estatisticamente entre si, nas cinco cultivares e nos dois sistemas de cultivo. Contudo, os fungicidas testados proporcionaram germinação das sementes superior a 90\% nas quatro cultivares.

Palavras-chaves: Fungicida, Oryza sativa, Tratamento de ementes.

\section{INTRODUCTION}

Leaf scald, caused by the fungus Microdochium albescens Thüm (Syn. Microdochium oryzae Hashioka \& Yokogi; Gerlachia oryzae Hashioka \& Yokogi), has been reported in all rice producing regions in the world (FARR et al., 2008). Seeds are considered a source of primary inoculum (OU, 1985; WEBSTER \& GUNNELL, 1992), and the transmission of the fungus in dryland cultivation occurs through infected seeds causing discoloration in the seedlings (FILIPPE et al., 2005; GUTIÉRREZ,
2008). Leaf scald reduces the number, weight and physiological quality of seeds (MOURA et al., 2014), causing up to $30 \%$ damage to yield (THOMAS, 1984). Companies seek to meet the standards of seed commercialization; and therefore, adopted measures for quality control using physiological tests, such as germination and vigor tests, and alternatives for maintaining quality through seed treatment.

Health tests for irrigated rice seeds from Santa Catarina crops, performed at the Phytopathology Laboratory of the Universitdade do Estado de Santa Catarina in the 2015/16, 2016/17 and 2017/18 
harvests revealed a $100 \%$ prevalence of $M$. albescens and average incidence greater than 50\% (SCHEIDT et al., 2020a) of the lots analyzed. According to the Technical Department of Cooperativa Cravil, responsible for the largest production of irrigated rice seeds in the state of Santa Catarina, the occurrence of leaf scald has increased considerably in irrigated rice crops in the pre-germinated cultivation system.

In crops such as soybeans and corn, seed treatment (ST) has been used to control fungi associated with the seed; however, in rice this practice does not occur with the same frequency, especially in the pre-germinated cultivation system, where there is no information and indications (SOSBAI, 2018).

The ST of rice aimed to control fungi by infecting and infesting seeds, soil fungi and also insects in case of the use of insecticide in addition to the fungicide, thus protecting the seedling in the early stages of the crop. Its use is essential to ensure germination, emergence, seedling formation, and consequent plant population, associated with crop yield (MENTEN \& MORAES, 2010).

ST is considered one of the low-cost cultural practices in the control of pathogens in upland rice (KIMATI et al., 1997); however, there is no information on the effect of fungicides on ST to control $M$. albescens in the system cultivation of pre-germinated rice (SOSBAI, 2018). It is believed that the product is diluted in water and has reduced efficiency and / or that there is a possible elimination of pathogens in the pre-germination process and subsequent seeding in water depths in the fields. However, the fungus is transmitted from seed to seedling in this system (SCHEIDT et al., 2020a), indicating that the elimination of pathogens from seeds does not occur by immersing them in water.

This research evaluated the efficiency of fungicides in the treatment of pre-germinated and dryland rice seeds in the control of $M$. albescens.

\section{MATERIALS AND METHODS}

The studies were conducted in vitro at the plant pathology laboratory of the University of the State of Santa Catarina (UDESC), Lages-SC, under a completely randomized design, in a $2 \times 7 \times 2$ trifactorial scheme (cultivation systems $x$ seed treatment $x$ evaluation days of the TS effect).

Seeds from cultivars Epagri 109, SCS116 Satoru, SCS121 CL and SCS122 Miura were used, produced in the Alto Vale do Itajaí in the 2017/18 harvest. Each cultivar constituted an isolated study. For the choice of fungicides, the molecules available on the market for ST in wheat and corn were considered, mainly for Fusarium control. Seven seed treatments were evaluated for each cultivar, six fungicides and one control, where: T1-fluazinam + thiophanate methyl $\left(9.45+63\right.$ g a.i) $\left(\right.$ Certeza $\left.^{\circledR}\right)$; T2-pyraclostrobin + thiophanate methyl $(5+45$ g a.i) $\left(\right.$ Standak Top $\left.{ }^{\circledR}\right)$; T3- carboxin + thiram $(60+$ 60 g a.i) (Vitavax Thiram $^{\circledR}$ ); T4- metalaxyl-M + thiabendazole + fludioxonil $(3+22.5+3.75 \mathrm{~g}$ a.i $)$ (Maxim Advanced $\left.{ }^{\circledR}\right)$; T5- carbendazim + thiram (45 +105 g a.i) (Derosal Plus ${ }^{\circledR}$ ); T6- carbendazim (45 g a.i) (Carbendazim Nortox ${ }^{\circledR}$ ) in doses of commercial producer per $100 \mathrm{~kg}$ of seed $^{-1}$ and T7- control, untreated. The seed treatment was carried out in the laboratory, wet ( $2 \%$ water), using $1 \mathrm{~kg}$ of seeds per treatment. After the application of the products, the seeds were packed in plastic bags, for homogenization. Then, they were put to dry in the shade and packed in paper bags, until the beginning of the tests.

After being treated, 400 seeds of each treatment were separated to simulate each cultivation system. In the pre-germinated system, the seeds were previously immersed in water (1:10 ratio, seed: water) for 30 hours, with subsequent removal and maintenance of them in a plastic tray in the shadow for the same period to induce the germination process (seeds at the "needle point"), phenological stage for sowing S3 (COUNCE, 2000; SOSBAI, 2018). For the dryland system the seeds were treated and not submitted to the pre-germination process.

The treated seeds were subjected to the health test by sowing them in Petri dishes containing PSA culture medium, plus antibiotics (streptomycin sulfate, $0.05 \%$ ). The dishes were incubated for seven and fourteen days in a growth chamber at a temperature of $25 \pm 2{ }^{\circ} \mathrm{C}$ and a photoperiod of 12 hours. The seeds under which it was possible to identify colonies and/ or structures of the fungus $M$. albescens observed under a binocular loupe and/or slide under an optical microscope were considered to be infected, the final incidence of the pathogen in treatments could be determined. However, to evaluate the efficiency of fungicides in treatments, the incidences were verified at 7 and 14 days after incubation in comparison to the control (untreated).

Germination was evaluated according to the Rules for Seed Analysis (BRASIL, 2009). Four replications of 100 seeds sown on Germitest ${ }^{\circledR}$ paper, moistened with distilled water at three times the weight of the paper, were used for each treatment, maintained at $25^{\circ} \mathrm{C}$ in germination chambers. The normal seedlings were evalueted after seven and fourteen days. 
The variables evaluated were subjected to analysis of variance and when found interactions or simple effects significant to the means were compared by the Tukey test, with a $5 \%$ probability of error. The assumptions of normality of residues and homogeneity of variance were verified through diagnostic analysis. When necessary, transformations to arc sen $\sqrt{ }(\mathrm{x} / 100)$ were performed to meet the assumptions. Statistical analyzes were performed using the statistical programs R software, version 3.4.1 (R CORE TEAM, 2017).

\section{RESULTS AND DISCUSSIONS}

All cultivars showed germination higher than $80 \%$ in both treatments, which is the minimum required for the commercialization of rice seeds in Brazil (BRASIL, 2013). No ST caused reduction in germination compared to the control, demonstrating that there was no phytotoxicity in the doses used (Table 1). Phytotoxicity was also not observed by LOBO (2008) when using TS with carboxin + thiram $(60+60 \mathrm{~g}$ a.i), tricyclazole (225 g a.i), azoxystrobin (100g a.i) and pyroquilon (400 g a.i).
Fluazinam + thiophanate methyl, carboxin + thiram, metalaxyl-M + thiabendazole + fludioxonil, carbendazim + thiram and carbendazim maintained the best germination percentages for the cultivar SCS121 CL; however, piraclostrobin + thiophanate methyl and carboxin + thiram did not show any difference (Table 1).

For cultivar SCS122 Miura, carboxin + thiram, metalaxyl-M + thiabendazole + fludioxonil and carbendazim + thiram present bed the highest and pyraclostrobin + thiophanate methyl the lowest germination percentage, not differing from the control (Table 1). According to PRABHU \& VIEIRA (1989) rice seeds, treated with carboxin + thiram showed maintenance of germination and better seedling health. The same was observed in cotton seeds (FARIA et al., 2003), and sorghum (NETTO et al., 1997) using the same assets. LENZ (2008), using seed treatment with carboxin + thiram observed that it did not interfere with the germination, emergence and speed of emergence index of rice seedlings. For cultivars SCS122 Miura and Epagri 109, all treatments had the

Table 1 - Percentage of germination of rice seeds of cultivars SCS121 CL, SCS122 CL, Epagri 109 and SCS116 Satoru, submitted to different treatments.

\begin{tabular}{|c|c|c|c|c|c|c|}
\hline \multirow[t]{2}{*}{ Treatment } & \multicolumn{3}{|c|}{ 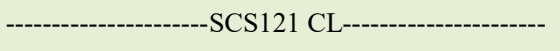 } & \multicolumn{3}{|c|}{ 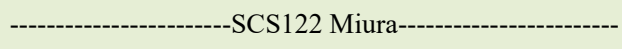 } \\
\hline & Normal & Abnormal & Dead & Normal & Abnormal & Dead \\
\hline $\mathrm{T} 1$ & $90 \mathrm{ab}$ & $4 \mathrm{ab}$ & $6 a b$ & $91 \mathrm{~b}$ & $4 \mathrm{c}$ & $5 \mathrm{~b}$ \\
\hline $\mathrm{T} 2$ & $88 \mathrm{bc}$ & $6 \mathrm{ab}$ & $6 \mathrm{ab}$ & $85 \mathrm{c}$ & $10 \mathrm{a}$ & $5 \mathrm{~b}$ \\
\hline $\mathrm{T} 3$ & $90 \mathrm{ab}$ & $3 \mathrm{bc}$ & $7 \mathrm{a}$ & $94 \mathrm{ab}$ & $3 \mathrm{c}$ & $3 \mathrm{~b}$ \\
\hline $\mathrm{T} 4$ & $92 \mathrm{a}$ & $1 \mathrm{c}$ & $7 \mathrm{a}$ & $95 \mathrm{a}$ & $0 \mathrm{~d}$ & $5 \mathrm{~b}$ \\
\hline T5 & $92 \mathrm{a}$ & $3 \mathrm{bc}$ & $5 \mathrm{ab}$ & $92 \mathrm{ab}$ & $4 \mathrm{c}$ & $4 \mathrm{~b}$ \\
\hline T6 & $91 \mathrm{ab}$ & $5 \mathrm{ab}$ & $4 \mathrm{~b}$ & $91 \mathrm{~b}$ & $5 \mathrm{bc}$ & $4 \mathrm{~b}$ \\
\hline $\mathrm{T} 7$ & $86 \mathrm{c}$ & $7 \mathrm{a}$ & $7 \mathrm{a}$ & $83 \mathrm{c}$ & $8 \mathrm{ab}$ & $9 \mathrm{a}$ \\
\hline \multirow[t]{2}{*}{ Average $^{*}$} & $90 \mathrm{~A}$ & $4 \mathrm{~B}$ & $6 \mathrm{~B}$ & $90 \mathrm{~A}$ & $5 \mathrm{~B}$ & $5 \mathrm{~B}$ \\
\hline & \multicolumn{3}{|c|}{----------------------EPAGRI 109------------------- } & \multicolumn{3}{|c|}{------------------------SCS1 16 Satoru----------------------' } \\
\hline $\mathrm{T} 1$ & $92 \mathrm{bc}$ & $6 \mathrm{a}$ & $2 \mathrm{~b}$ & $92 \mathrm{bc}$ & $4 \mathrm{ab}$ & $4 \mathrm{ab}$ \\
\hline $\mathrm{T} 2$ & $91 \mathrm{c}$ & $5 \mathrm{ab}$ & $4 \mathrm{~b}$ & $88 \mathrm{~cd}$ & $7 \mathrm{a}$ & $5 \mathrm{ab}$ \\
\hline $\mathrm{T} 3$ & $94 \mathrm{ab}$ & $3 \mathrm{bc}$ & $3 \mathrm{~b}$ & $94 \mathrm{~b}$ & $3 \mathrm{~b}$ & $3 \mathrm{~b}$ \\
\hline $\mathrm{T} 4$ & 96 a & $1 \mathrm{c}$ & $3 \mathrm{~b}$ & 97 a & $1 \mathrm{c}$ & $2 \mathrm{~b}$ \\
\hline T5 & $92 \mathrm{bc}$ & $5 \mathrm{ab}$ & $3 \mathrm{~b}$ & $92 \mathrm{bc}$ & $4 \mathrm{ab}$ & $4 a b$ \\
\hline T6 & $93 \mathrm{bc}$ & $3 \mathrm{bc}$ & $4 \mathrm{~b}$ & $93 \mathrm{~b}$ & $4 a b$ & $3 a b$ \\
\hline $\mathrm{T} 7$ & $86 \mathrm{~d}$ & $6 a$ & $8 \mathrm{a}$ & $88 \mathrm{~d}$ & $6 \mathrm{a}$ & $6 a$ \\
\hline Average $^{*}$ & $92 \mathrm{~A}$ & $4 \mathrm{~B}$ & $4 \mathrm{~B}$ & $92 \mathrm{~A}$ & $4 \mathrm{~B}$ & $4 \mathrm{~B}$ \\
\hline CV (\%) & -------------. & ----16,4---- & ---------- & -------------- & ----16,4----. & ------------ \\
\hline
\end{tabular}

T1) fluazinam + thiophanate methyl; T2) pyraclostrobin + thiophanate methyl; T3) carboxin + thiram; T4) metalaxyl-M + thiabendazole + fludioxonil; T5) carbendazim + thiram; T6) carbendazim; T7) control. ${ }^{*}$ Averages followed by the same letter in the columns do not differ by Tukey's test $(\mathrm{P}<0.05)$. 
lowest percentage of seedlings death compared to the control. The highest percentage of abnormal seedlings was reported in the cultivar SCS122 Miura with the treatment pyraclostrobin + thiophanate methyl, where it did not differ from the control.

In the cultivars Epagri 109 and SCS116 Satoru the ST with metalaxyl-M + thiabendazole + fludioxonil stood out with the highest percentage of germination; however, in the cultivar Epagri 109, fluazinam + thiophanate methyl, pyraclostrobin + thiophanate methyl, carbendazim + thiram and carbendazim did not have statistical differences. To cultivate SCS116 Satoru, pyraclostrobin + thiophanate methyl obtained the lowest germination values, not differing from the control (Table 1).

Regardless of the cultivar, the fungicide carbendazim had the same incidence of the fungus and control at 7 and 14 days. This can be explained because at seven days all the seeds of the Petri dish had some fungus present in them, mainly fungi of the family Dematiaceae, in which carbendazim has no fungitoxic action on them.
The incidence of $M$. albescens present in the seeds used in the experiment was enough to discriminate the efficiency of the fungicides (Table 2). All treatments tested obtained percentages of control of the fungus associated with the seeds; however, there were significant differences in control according to the active ingredient (Table 3 ).

Regardless of the cultivar, the active ingredients fluazinam + thiophanate methyl and metalaxyl-M + thiabendazole + fludioxonil did not present statistical differences for the variables days and cultivation systems, obtaining the lowest percentages of incidence (Table 2) and greater control of the fungus (Table 3 ), proving the greater efficiency and persistence of these products in relation to the others. However, treatments with pyraclostrobin + thiophanate methyl and carbendazim showed a higher percentage of fungi incidence in the seeds, characterizing less control, for both systems. According to GARCIA JUNIOR (2008), the fungicides thiabendazole and thiophanate methyl were superior to triflumizole and triadimenol in the treatment of wheat seeds to

Table 2 - Incidence of Microdochium albescens (\%) with different treatment of pre-germinated and dryland rice seeds of cultivars SCS121 CL, Epagri 109, SCS116 Satoru and SCS122 Miura.

\begin{tabular}{|c|c|c|c|c|c|c|c|c|}
\hline \multirow{3}{*}{ Treat } & \multicolumn{4}{|c|}{ 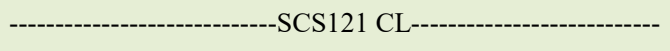 } & \multicolumn{4}{|c|}{---------------------------Epagri 109------------------------- } \\
\hline & \multicolumn{2}{|c|}{------------Dryland---------- } & \multicolumn{2}{|c|}{-------Pre-germinated------ } & \multicolumn{2}{|c|}{----------Dryland---------- } & \multicolumn{2}{|c|}{-------Pre-germinated------- } \\
\hline & 7 & 14 & 7 & 14 & 7 & 14 & 7 & 14 \\
\hline $\mathrm{T} 1$ & $5.5 \mathrm{dAI}$ & $6.0 \mathrm{dAI}$ & $5.0 \mathrm{dAI}$ & $6.5 \mathrm{eAI}$ & $4.5 \mathrm{cAI}$ & $5.5 \mathrm{eAI}$ & $5.0 \mathrm{dAI}$ & $5.5 \mathrm{eAI}$ \\
\hline $\mathrm{T} 2$ & $25.5 \mathrm{cBI}$ & $32.0 \mathrm{bAI}$ & $55.0 \mathrm{bBV}$ & $65.0 \mathrm{aAV}$ & $20.0 \mathrm{bBI}$ & $26.0 \mathrm{cAI}$ & $40.0 \mathrm{bAV}$ & $45.5 \mathrm{bAV}$ \\
\hline $\mathrm{T} 3$ & $6.0 \mathrm{dBI}$ & $22.0 \mathrm{cAI}$ & $20.0 \mathrm{cBV}$ & $38.0 \mathrm{cAV}$ & $7.5 \mathrm{cBI}$ & $16.5 \mathrm{dAI}$ & $15.0 \mathrm{cBV}$ & $31.5 \mathrm{cAV}$ \\
\hline $\mathrm{T} 4$ & $6.5 \mathrm{dBI}$ & $11.0 \mathrm{dAI}$ & $7.5 \mathrm{dAI}$ & $10.0 \mathrm{eAI}$ & $8.0 \mathrm{cAI}$ & $8.5 \mathrm{de} A \mathrm{I}$ & $9.0 \mathrm{cdAI}$ & $12.0 \mathrm{de} A \mathrm{I}$ \\
\hline T5 & $5.5 \mathrm{dBI}$ & $21.5 \mathrm{cAI}$ & $17.5 \mathrm{cAV}$ & $22.0 \mathrm{dAI}$ & $8.0 \mathrm{cAI}$ & 12.5 deAI & 11.5 cdAI & $15.5 \mathrm{dAI}$ \\
\hline T6 & $36.0 \mathrm{bAI}$ & $36.0 \mathrm{bAI}$ & $59.5 \mathrm{bAV}$ & $59.5 \mathrm{bAV}$ & $27.0 \mathrm{bAI}$ & $27.0 \mathrm{bAI}$ & $51.5 \mathrm{bAV}$ & $51.5 \mathrm{bAV}$ \\
\hline $\mathrm{T} 7$ & $52.0 \mathrm{aAI}$ & $52.0 \mathrm{aAI}$ & $75.0 \mathrm{aAV}$ & $75.0 \mathrm{aAV}$ & $45.0 \mathrm{aAI}$ & $45.0 \mathrm{aAI}$ & $60.0 \mathrm{aAV}$ & $60.0 \mathrm{aAV}$ \\
\hline Average & $19.6 \mathrm{BI}$ & $27.4 \mathrm{AI}$ & $34.2 \mathrm{BV}$ & $42.4 \mathrm{AV}$ & $17.3 \mathrm{BI}$ & $21.4 \mathrm{AI}$ & $26.8 \mathrm{BV}$ & $31.6 \mathrm{AV}$ \\
\hline \multirow[t]{2}{*}{ C.V. $(\%)$} & \multicolumn{4}{|c|}{-------------------------------10.73-------------------------------- } & \multicolumn{4}{|c|}{------------------------------16.87----------------------------- } \\
\hline & \multicolumn{4}{|c|}{ 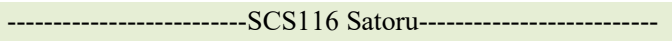 } & \multicolumn{4}{|c|}{--------------------------SCS122 Miura---------------------- } \\
\hline $\mathrm{T} 1$ & $4.5 \mathrm{cAI}$ & $6.0 \mathrm{eAI}$ & $5.5 \mathrm{dAI}$ & $6.5 \mathrm{dAI}$ & $5.0 \mathrm{dAI}$ & $5.5 \mathrm{dAI}$ & $5.0 \mathrm{eAI}$ & $6.0 \mathrm{eAI}$ \\
\hline $\mathrm{T} 2$ & $28.5 \mathrm{bBI}$ & $35.0 \mathrm{bcAI}$ & $38.0 \mathrm{cBV}$ & $43.0 \mathrm{bAI}$ & $22.0 \mathrm{cBI}$ & $37.0 \mathrm{bAI}$ & $50.0 \mathrm{bBV}$ & $57.5 \mathrm{bAV}$ \\
\hline T3 & $5.5 \mathrm{cBI}$ & $18.0 \mathrm{cAI}$ & $9.5 \mathrm{dBI}$ & $22.0 \mathrm{cAV}$ & $6.0 \mathrm{dBI}$ & $23.0 \mathrm{cAI}$ & $28.5 \mathrm{cBV}$ & $37.0 \mathrm{cAI}$ \\
\hline $\mathrm{T} 4$ & $7.5 \mathrm{cAI}$ & 9.0 deAI & $8.5 \mathrm{dAI}$ & $10.5 \mathrm{dAI}$ & $7.0 \mathrm{dAI}$ & $8.5 \mathrm{dAI}$ & $5.0 \mathrm{eAI}$ & $7.0 \mathrm{eAI}$ \\
\hline $\mathrm{T} 5$ & $9.5 \mathrm{cBI}$ & $15.0 \mathrm{dAI}$ & $13.0 \mathrm{dBI}$ & $19.0 \mathrm{cAI}$ & $7.0 \mathrm{dBI}$ & $20.0 \mathrm{cAI}$ & $16.5 \mathrm{dBV}$ & $24.0 \mathrm{dAI}$ \\
\hline T6 & $28.0 \mathrm{bAI}$ & $28.0 \mathrm{cAI}$ & $58.0 \mathrm{bAV}$ & $58.0 \mathrm{aAV}$ & $32.0 \mathrm{bAI}$ & $32.0 \mathrm{bAI}$ & $50.0 \mathrm{bAV}$ & $50.0 \mathrm{bcAV}$ \\
\hline $\mathrm{T} 7$ & $47.0 \mathrm{aAI}$ & $47.0 \mathrm{aAI}$ & $66.0 \mathrm{aAV}$ & $66.0 \mathrm{aAV}$ & $62.0 \mathrm{aAI}$ & $62.0 \mathrm{aAI}$ & $78.0 \mathrm{aAV}$ & $78.0 \mathrm{aAV}$ \\
\hline Average & $18.6 \mathrm{BI}$ & $24.8 \mathrm{AI}$ & $27.6 \mathrm{BV}$ & $33.3 \mathrm{AV}$ & 19.7 BI & $29.6 \mathrm{AI}$ & $32.9 \mathrm{BV}$ & 37.6 AV \\
\hline C.V (\%) & \multicolumn{4}{|c|}{ 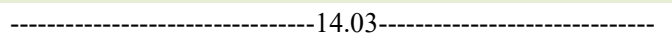 } & \multicolumn{4}{|c|}{---------------------------------16.25------------------------------ } \\
\hline
\end{tabular}

T1) fluazinam + thiophanate methyl; T2) pyraclostrobin + thiophanate methyl; T3) carboxin + thiram; T4) metalaxyl-M + thiabendazole + fludioxonil; T5) carbendazim + thiram; T6) carbendazim; T7) control. * Means followed by the same letter, lower case in the column, upper case in the line and Roman numbers between systems, do not differ by the Tukey test $(\mathrm{P}<0.05)$. 
Table 3 - Percentage of control of Microdochium albescens with different treatment of pre-germinated and dryland rice seeds of cultivars SCS121 CL, Epagri 109, SCS116 Satoru and SCS122 Miura.

\begin{tabular}{|c|c|c|c|c|c|c|c|c|}
\hline \multirow[t]{2}{*}{ Treat } & \multicolumn{2}{|c|}{-------Dryland------- } & \multicolumn{2}{|c|}{---Pre-germinated--- } & \multicolumn{2}{|c|}{---------Dryland------- } & \multicolumn{2}{|c|}{----------Pre-germinated--------- } \\
\hline & 7 & 14 & 7 & 14 & 7 & 14 & 7 & 14 \\
\hline $\mathrm{T} 1$ & 89.4 & 88.5 & 93.3 & 91.3 & 90.0 & 87.8 & 91.0 & 90.8 \\
\hline $\mathrm{T} 2$ & 50.9 & 38.0 & 26.7 & 13.3 & 55.5 & 42.2 & 33.3 & 24.2 \\
\hline $\mathrm{T} 3$ & 88.5 & 57.0 & 73.3 & 50.7 & 83.3 & 63.3 & 75.0 & 47.5 \\
\hline $\mathrm{T} 4$ & 87.5 & 78.8 & 90.0 & 86.7 & 82.2 & 81.1 & 85.0 & 80.0 \\
\hline T5 & 89.4 & 58.6 & 76.6 & 70.7 & 82.2 & 72.2 & 80.0 & 74.2 \\
\hline T6 & 30.8 & 30.8 & 20.7 & 20.7 & 40.0 & 40.0 & 14.2 & 14.2 \\
\hline Average $(\%)$ & 72.8 & 58.6 & 63.4 & 55.6 & 72.2 & 64.4 & 63.1 & 55.2 \\
\hline \multicolumn{5}{|c|}{ 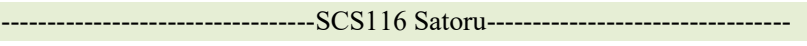 } & \multicolumn{4}{|c|}{---------------------------SCS122 Miura------------------------ } \\
\hline $\mathrm{T} 1$ & 90.4 & 87.2 & 91.7 & 90.2 & 91.0 & 91.1 & 93.0 & 92.3 \\
\hline $\mathrm{T} 2$ & 39.4 & 25.5 & 42.4 & 34.8 & 64.5 & 40.3 & 35.8 & 26.3 \\
\hline $\mathrm{T} 3$ & 88.3 & 61.0 & 85.6 & 66.0 & 90.3 & 62.9 & 63.5 & 52.6 \\
\hline $\mathrm{T} 4$ & 84.0 & 80.8 & 87.1 & 84.1 & 88.7 & 86.3 & 93.6 & 91.0 \\
\hline T5 & 79.7 & 68.1 & 80.3 & 71.2 & 88.7 & 67.7 & 78.8 & 69.2 \\
\hline T6 & 40.4 & 40.4 & 12.12 & 12.12 & 48.4 & 48.4 & 35.9 & 35.9 \\
\hline Average (\%) & 70.4 & 60.5 & 66.5 & 59.7 & 78.6 & 66.1 & 66.8 & 61.2 \\
\hline
\end{tabular}

T1) fluazinam + thiophanate methyl; T2) pyraclostrobin + thiophanate methyl; T3) carboxin + thiram; T4) metalaxyl-M + thiabendazole + fludioxonil; T5) carbendazim + thiram; T6) carbendazim; T7) control.

control Fusarium graminearum Schwabe. According to AGOSTINETTO et al. (2018) fungicide mixtures with the presence of carbendazim and / or carboxin + thiram had greater control of $F$. graminearum in barley seeds. Likewise, HENNING et al. (2009), using black oat seed treatment, determined that the carbendazim + thiram fungicides removed the fungi of the Fusarium genus from the seeds.

The active ingredients carboxin + thiram and carbendazim + thiram were more efficient in the control up to seven days, in the dryland cultivation system compared to the pre-germinated system, but even in dryland, they were not persistent until the 14 days (Table 2 and 3). LOBO (2008), when evaluating the phytosanitary quality of rice seeds under the chemical treatment with carboxin + thiram $(60+60 \mathrm{~g}$ a.i $)$ and tricyclazole $(225 \mathrm{~g}$ a.i $)$, observed a $100 \%$ control for $M$. albescens when it affected 22.5 $\%$ of seeds (control). The average incidence of $M$. albescens in this study is high (greater than or equal to $45 \%$ ), which reduced the possibility of controls occurring by $100 \%$.

The average incidence of $M$. albescens in the control treatment was higher in the pre-germinated cultivation system, regardless of the cultivar. This can be explained by placing the seeds to pre-germinate, the embryo, initially protected and possibly infected, is externalized. In this way, there is an increase in the probability of detection in relation to dryland seeds, since the fungus inside the seed is exteriorized close to the root (Tables 2).

There is no information for the chemical treatment of irrigated rice seeds in the pre-germinated cultivation system. Thus, the information obtained in this study is of great importance for the management of $M$. albescens in this system. It is recommended to evaluate active ingredients in isolation as well as different doses in order to give greater support to this research.

\section{CONCLUSIONS}

Seed treatments with fluazinam + thiophanate methyl, carboxin + thiram, metalaxyl-M + thiabendazole + fludioxonil, carbendazim + thiram show control over $70 \%$ of the fungus $M$. albescens up to seven days after sowing pre-germinated rice seeds and dry in PSA + A culture medium.

The active ingredients fluazinam + thiophanate methyl and metalaxyl-M + thiabendazole + fludioxonil show greater efficiency and persistence at 7 and 14 days after sowing pre-germinated and 
dryland rice seeds in $\mathrm{PSA}+\mathrm{A}$ culture medium compared to pyraclostrobin + thiophanate methyl, carboxin + thiram, carbendazim + thiram and carbendazim with control over $80 \%$.

Seed treatment is a crucial tool in integrated disease management for both cropping systems.

\section{ACKNOWLEDGEMENTS}

The research was financed in part by the Coordenação de Aperfeiçoamento de Pessoal de Nível Superior (CAPES), Brasil, Finance code 001.

\section{DECLARATION OF CONFLICT OF INTEREST}

The authors declared no conflict of interest. The founding sponsors had no role in the design of the study; in the collection, analyses, or interpretation of data; in the writing of the manuscript, and in the decision to publish the results.

\section{AUTHORS' CONTRIBUTIONS}

BTS, RTC and EZF conceived and designed experiments. BTS, FCM and MMDP performed the experiments and carried out the lab analysis. BTS, JB prepared the draft of the manuscript. All authors critically revised the manuscript and approved of the final version.

\section{REFERENCES}

AGOSTINETTO, L. et al. Viabilidade e controle de Fusarium graminearum em sementes de cevada. Summa Phytopathologica, v.44, n.4, p.368-373, 2018. Available from: <https://www. researchgate.net/publication/330896632>. Accessed: Jan. 15, 2020. doi: $10.1590 / 0100-5405 / 185017$.

BRASIL. Ministério da Agricultura, Pecuária e Abastecimento. Instrução Normativa $\mathbf{n}^{\mathbf{0}}$. 45. Brasília: MAPA, 2013. Available from: $\quad<$ https://www.gov.br/agricultura/ptbr/assuntos/insumosagropecuarios/insumosagricolas/ sementes-e-mudas/publicacoes-sementes-e-mudas/ copyofINN45de17desetembrode2013.pdf > . Accessed: Feb. 18, 2020.

BRASIL. Ministério da Agricultura Pecuária e Abastecimento. Teste de sanidade de sementes. In: Regras para a análise de sementes. Brasília: MAPA/ACS, 2009, Cap.9, p.335-340. <https:// www.gov.br/agricultura/pt-br/assuntos/insumos-agropecuarios/ insumos-agricolas/sementes-e-mudas/publicacoes-sementes-emudas/INN29de5deagostode2009Completa.Pd f/view $>$. Accessed: Feb. 07, 2020.

COUNCE, P. A. et al. A uniform, objective, and adaptative system for expressing rice development. Crop Science, Madison, v.40, p.436-443, 2000. Available from: <https://acsess.onlinelibrary. wiley.com/doi/abs/10.2135/cropsci2000.402436x>. Accessed: Jan. 12, 2020. doi. 10.2135/cropsci2000.402436x.

FARIA, A. Y. K. et al. Physiological quality of cotton seeds submitted to chemical and biological treatments. Revista Brasileira de Sementes, v.25, p.121-127, 2003. Available from:
$<$ https://www.scielo.br/j/rbs/a/zC64ZZsqNTtRbvbWMvmYkPQ/ abstract/?lang=pt $>$. Accessed: Aug. 05, 2020. doi: 10.1590/S010131222003000100019 .

FARR, D. F.; ROSSMAN, A.Y. Fungal Databases, Systematic Mycology and Microbiology Laboratory, ARS, USDA, 2008. Online. Available from: <http://nt.ars-grin.gov/fungaldatabases/>. Accessed: Aug. 16, 2020.

FILIPPI, M. C. et al. Escaldadura do arroz e seu controle. Circular técnica 72. Santo Antônio de Goiás. Embrapa Arroz e Feijão. 2005, 4p.

GARCIA JÚNIOR, D. et al. Effects of fungicides on Fusarium graminearum control, germination, emergency and e height of seedlings in wheat seeds. Summa Phytopathologica, v.34, p.280283, 2008. Available from: <https://www.scielo.br/j/sp/a/yK9Bj yyszdyKcyBjD8stNzR/?lang=pt $>$. Accessed: Jan. 27, 2020. doi: 10.1590/S0100-54052008000300018.

GUTIÉRREZ, S. A. et al. Detection and transmission of Microdochium oryzae from rice seed in Argentina. Australian Plant Disease. v.3, p.75-77, 2008. Available from: <https:// link.springer.com/content/pdf/10.1007\%2FBF03211246.pdf>. Accessed: Jul. 20, 2020. doi: 10.1071/DN08030.

HENNING, F. A. et al. Physiological, sanitary quality and isoenzyme analysis of black oat seeds treated with different fungicides. Revista Brasileira de Sementes. v.31, p.63-69, 2009. Available from: $<$ https://www.scielo.br/j/rbs/a/vSM3Jbn89QmCW hwHgZLkLRB/?lang=pt>. Accessed: Jan. 18, 2020. doi: 10.1590/ S0101-31222009000300007.

KIMATI, H. et al. Guia de fungicidas agrícolas: recomendações por cultura. 2.ed. Jaboticabal: Grupo Paulista de Fitopatologia, 1997. v.1, 224p.

LENZ, G. et al. Fungicide phytotoxicity on rice (Oryza sativa) seeds. Revista da FZVA. v.15, p.53-60, 2008.

LOBO, V. S. Effects of chemical treatment of rice seeds on leaf blast control and physiological and sanitary quality of treated seeds. Tropical Plant Pathology. v.33, p.162-166, 2008. Available from: $<$ https://www.scielo.br/j/tpp/a/yDdqsB93RhsbG4htKYbL8VB/>. Accessed: Jul. 18, 2020. doi: 10.1590/S1982-56762008000200012.

MENTEN, J. O. M.; MORAES, M.H.D. Tratamento de sementes: histórico, tipos, características e benefícios. Informativo ABRATES, v.20, n.3, p.52-71, 2010. <http://www.abrates.org.br/ images/stories/informativos/v20n3/minicurso03.pdf.> Accessed: Jul. 16, 2020.

MOURA, A. B. et al. Biocontrol and seed transmission of Bipolaris oryzae and Gerlachia oryzae to rice seedlings. Journal of Seed Science, v.36, p.407-412, 2014. Available from: $\quad<$ http://www.scielo.br/scielo.php?script=sci_arttext\&pid $=$ S2317-15372014000400004 $>$. Accessed: Jan. 12, 2020. doi: $10.1590 / 2317-1545 \mathrm{v} 36 \mathrm{n} 41009$.

NETTO, D. A. M. et al. Sorghum (Sorghum bicolor (L.) Moench.) seed damaged physiological quality after storage, v.19, p.342348, 1997.

OU SH. Rice diseases. (Commonwealth Mycological Institute: Kew), 1985. 380 p. 
PRABHU, A. S.; VIREIRA, N. R. A. Sementes de arroz infectadas por Drechslera oryzae: germinação, transmissão e controle. Goiânia GO. Embrapa Arroz e Feijão. Boletim n.7 39p. CNPAF, 1989. <https://www.embrapa.br/busca-depublicacoes/publicacao/191599/sementes -de-arroz-infectadaspor-drechslera-oryzae-germinacao-transmissao-e-controle $>$. Accessed: Feb. 20, 2020.

R CORE TEAM. R: A language and environment for statistical computing. R Foundation for Statistical Computing, Vienna, Áustria, 2017.

SCHEIDT, B.T. et al. Fungi on irrigated rice seeds produced in the pre-germinated system in the Alto Vale do Itajaí region, Santa Catarina state, Brazil. Ciência Rural, Santa Maria, v.50, n.8, p.e20190903, 2020: Available from: <https://www.scielo.br/j/cr/a/ MKL6Mk8w6DHDpLxJ3wGdkQp/>. Accessed: Aug. 21, 2020. doi: $10.1590 / 0103-8478 \mathrm{cr} 20190903$.
SCHEIDT, B. T. et al. Transmission of Microdochium albescens from seeds to seedlings in the pre-germinated cultivation system of irrigated rice. Ciência Rural. v.50, e20180898, 2020: Available from: < https://doi.org/10.1590/0103-8478cr20180898>. Accessed: Feb. 21, 2020. doi: 10.1590/0103-8478cr20180898.ei.

SOSBAI. Arroz irrigado: recomendações técnicas da pesquisa para o Sul do Brasil / Sociedade Sul-Brasileira de Arroz Irrigado; XXXII Reunião Técnica da Cultura do Arroz Irrigado. Farroupilha, RS, p.205, 2018. Online. Available from: $<$ http://www.sosbai.com. br/docs/Boletim_RT_2018.pdf>. Accessed: Oct. 21, 2019.

THOMAS, M.D. Dry-season survival of Rhynchosporium oryzae in rice leaves and stored seeds. Mycologia. v.76, p.11111113, 1984.

WEBSTER, R. K.; GUNNELL, P. S. Compendium of rice diseases. St. Paul: The American Phytopathological Society. 1992. 62p. 